\title{
Human Security after 25 Years: Some Introductory Remarks and Critical Reflections
}

\author{
Sorpong Peou
}

\begin{abstract}
After 25 years, the global vision for human security as a concept and a policy commitment remains unfulfilled in most parts of the world. In fact, more and more evidence points to the growing reality that the idea of securing people has once again succumbed to the traditional concepts of state security and regime security, as it did after World War II. Part of the problem can be found in some major policy instruments adopted by proponents of human security. Military intervention for human protection, economic sanctions and judicial punishment or threats thereof, which have been regarded as policy instruments to protect people or promote human security, have proved to be either insufficient or ineffective, and at worst counter-productive.
\end{abstract}

Keywords human security, regime, national security, military intervention, peacebuilding, smart sanctions

\section{Introduction}

This special issue provides an assessment of human security as a concept, now 25 years in the making. The big question for us is whether there is enough evidence to show that the security of individual human beings has been sufficiently promoted and actually enhanced on a global scale. Although there is a general agreement that human security differs from other concepts of security, given that people serve as the referent object of human security, people in various parts of the world, especially those in the non-Western regions, are far from secure. In spite of the early euphoria about the promise of human security, recent developments have proved to be far from positive. The 1990s was one of the most optimistic or hopeful decades in world history. The last decade of the 20th century seemed primed to bring change and hope back to the world, which had endured the breakout and destruction of World War I (1914-1918), the Great 
Depression (the 1930s), World War II (1939-1945), and the Cold War (1947-1991). In comparison, the end of the Cold War gave rise to a new sense of optimism about the future of the world and humanity. In 1989, the United Nations (UN) General Assembly declared The 1990s is as the decade of international law. Thus, in contrast the 1990s is also known as the "sanctions decade," as the number of economic sanctions imposed on states or regimes that violated international law increased (Cortright and Lepez 2002, 2000).

The 1990s also witnessed a shift in emphasis in international law from state sovereignty and national security to the rights and security of individuals. Although the UN General Assembly adopted the Universal Declaration of Human Right in 1948, human rights was not well protected and promoted throughout the Cold War because of power politics. Mass atrocities were committed by state authorities in the name of national security or ideology, such as those that took place in so-called socialist or communist countries (Courtois et al. 1999). It was not until after the end of the Cold War that much more attention was paid to gross human rights violations such as those that took place in the former Yugoslavia and Rwanda during the first half of the 1990s. In the midst of such developments, the idea of human security emerged.

Much has been written about human security (Hanlon and Christie 2016; Peou 2014a; MacFarland and Khong 2006), but more work is needed to assess the impact of this concept on human life. After 25 years, the global vision for human security as a concept and a global policy commitment remains unfulfilled in many parts of the world. In fact, more and more evidence points to the growing reality that the idea of securing people has once again succumbed to the traditional concepts of state security and regime security, as it did after World War II. Part of the problem can be found in some policy instruments adopted by proponents of human security. Military intervention for human protection, economic sanctions and judicial punishment or threats thereof, which were regarded as policy instruments to protect people or promote human security, have proved to be either insufficient or ineffective and at worst counter-productive.

\section{Human Security: In the Beginning}

It may be useful to clarify that human rights and human security are not quite the same, although some of their conceptual aspects overlap. Human rights are concerned with the way in which governments treat their peoples who are assumed to enjoy universal rights such as civil and political rights as well as economic, social and cultural rights. Human security is more about human survival or more broadly freedom from threat to human wellbeing. In the study of human security, proponents seek to answer the following questions: What are human beings secured against? Who provides for this type of security? How (what 
are the policy instruments)?

The concept of human security was first formalized by the United Nations Development Programme (UNDP) in its Human Development Report published in 1994. The UNDP's concept of security posed a direct challenge to the traditional concepts of security, most notably national security, international security, common security, comprehensive security, and comprehensive security (Peou 2014a). Unlike these other concepts that are state-centric, human security is about the security of individual human beings. In other words, individual human beings, not states, are the main referent object of security. According to UNDP, "human security is people-centred" (UNDP 1994, 23; italics added). It is also worth noting that proponents of human security do not say that all humans are equally insecure, as some more secure than others. They pay most of their attention to civilian populations vulnerable to direct and indirect violence.

The UNDP approach implicitly answers the above questions. Characterized as "broad" or "comprehensive," the UNDP defines security as "freedom" in two dimensions: "freedom from fear" and "freedom from want" (ibid.). The list of threats to these two types of freedom includes the following: economic security, food security, health security, environmental security, personal security, community security, and political security. It is worth noting that the idea of securing people through these two freedoms can be traced back to 1941 when U.S. President Franklin D. Roosevelt (FDR) delivered a major speech that laid out four freedoms: freedom of speech, freedom of worship, freedom from want, and freedom from fear (Engel 2016). The UNDP idea, however, has led its proponents in two different but arguably mutually reinforcing paths: "development-based" and "protection-based" (MacFarland and Khong 2006). The development-based path gives priority to freedom from want, centered on the idea of prevention rather than intervention, bottom-up rather than top-down, placing emphasis on social-economic or human development rather than coercive international intervention. The protection-based approach is more about securing vulnerable civilian populations, through coercive intervention against sources of physical violence, such as armed conflicts and mass atrocities (war crimes, genocide, ethnic cleansing, and crimes against humanity).

According to the UNDP, freedom from fear means freedom from direct physical violence, which includes a number of threats to community security and personal security: sectarian and ethnic violence, threats from the state (physical torture), threats from other states (war), threats from other group of people (ethnic tension), threats from individuals or gangs against other individuals or gangs (crime and street violence), and threats directed at children based on their vulnerability and dependence (child abuse). Proponents of freedom from fear paid attention to these sources of human insecurity resulting from the tragic events after the end of the Cold War, such as intra-state armed conflicts and mass atrocities which took place in countries like the former Yugoslavia 
and Rwanda, where unarmed civilian populations based on their religious and ethnic backgrounds were subjected to what came to be known as war crimes, genocide, ethnic cleansing, and crimes against humanity. Policy instruments designed to deal with threats to freedom from fear include military intervention, economic sanctions, and judicial deterrence/punishment or its threat. The North Atlantic Treaty Organization's military intervention in the Libya in 2011 is the first and best example of international efforts to protect people within the context of Responsibility to Protect (R2P), at a time when the leadership of Libya was accused of committing crimes against its own people or, additionally, suspected to have been prepared for more violence against them (Daalder and Stavridis 2012; Bellamy 2011). Smart sanctions have also been advocated and adopted to protect people (Cortright and Lepez 2002). Another type of global action taken to address mass atrocities was the establishment of the International Criminal Tribunal for the Former Yugoslavia and the International Criminal Tribunal for Rwanda. Subsequently other international criminal tribunals and courts were established, and among them was the International Criminal Court.

Freedom from want is much broader than freedom from fear and is generally defined as freedom from indirect or structural violence against individual human beings. Freedom from want is not the same as human development, which means enlarging people's choices and freedoms. However, freedom from want means freedom from socio-economic and environmental threats that limit people's choices and freedoms. Specific indicators include poverty, hunger, diseases and unhealthy lifestyles, socio-economic inequalities, and unsustainable development because of growing world population and environmental destruction. Proponents of human security have paid attention the threat of environmental degradation to future human survival and well-being (Mohajan 2015). They adopted the idea of "sustainable development," formulated by the World Commission on Environment and Development $(1987,8)$ making the case that development is "sustainable" when it "meets the [human] needs of the present without compromising the ability of future generations to meet their own needs." Global climate change and the loss of biodiversity have given rise to the politics of scarcity. There is, thus, a need to preserve our global commons and ensure environmental security if our welfare and security are to be maintained and a sense of urgency to motivate different actors to take collective action that would reverse environmental threats (Brainard et al. 2009). In September 2015, 193 UN member states adopted the 2030 Agenda for Sustainable Development with seventeen goals to ensure world peace and prosperity for both people and the planet.

In short, the idea of human security has its historical root that can be traced back to at least in the early 1940s when World War II was raging and it was not until after the end of the Cold War that it received renewed attention. The year 1994 marked the beginning of a UN push for the idea of securing human beings 
in addition to the protection of their individual rights.

\section{A Critical Reflection on Human Security after 25 Years}

Whether individual human beings have become more secure in the last twentyfive years is a matter of debate and further research. But what is clear is that the idea of human security has been confronted with several major challenges: empirical, conceptual, theoretical, and methodological.

Empirically, global trends since the end of the first decade of the 21st century appear mixed and full of uncertainty. On the one hand, proponents of human security have observed some positive developments. In the Asia-Pacific, for instance, they highlight what major countries like Australia, Japan and South Korea have done to improve human security. Australia is said to have coordinated with Japan, Indonesia and the Pacific Islands Forum on this front. Through such efforts, Japan has engaged in peacebuilding in fragile states. Some Japanese writers characterize the Japanese approach to human security on the basis of the "Tokyo Consensus" (Hoshino and Satoh 2016). Even sovereign-centric states like China appear to be moving slowly in this direction, despite the fact that the term of human security has yet to appear on the government's policy agenda and despite Chinas' "people-first" doctrine and its "new approach to human security" (Xiao and Yanxing 2016; Jiadong and Xin 2016).

On the other hand, much of what has been positively observed tends to highlight freedom from want in terms of policy commitment to such issues as health care, energy security, and environmental protection. At the same time, governments in various regions of the world remain overwhelmingly committed to the concept of national security or regime security. In spite of the vast amount of talking and writing about human security, efforts at realizing it are far from ideal. In the words of a proponent of human security, "despite the commissions, resolutions, reports, declarations and a multimillion-dollar Trust Fund, and despite the consensus of like-minded countries on the protection of people, human security is far from having been achieved, or even adopted as a global - let alone national - goal" (Tadjbakhsh 2014, 2). In her assessment, "the term 'human security' still courts rejection twenty years after its inception" (ibid.).

Even some democratic countries like Canada and Norway that used to embrace human security no longer explicitly embrace the concept (Peou 2009). After coming to power in 2006, the conservative government shelved the concept and slashed the funding. The country "dropped out of sight internationally as a promoter of the concept" (Small 2016, 1). The liberal government, formed after the 2015 election, did better in terms of its commitment to human rights, but the Canadian contribution to peacekeeping diminished substantially: only sixty-eight troops in 2017 and 112 in 2016. During the Cold War and into the 1990s, Canada 
was one of the world's top contributors to UN peacekeeping operations (with over 3,000 troops).

Even countries that keep human security on their policy agendas still largely adhere to national security. In the Asia-Pacific, where countries are known for their economic 'miracles', states remain Westphalian in policy orientation as they remain wedded to state sovereignty and security, still "preoccupied with protecting autonomy and independence, retaining a gatekeeping role, and avoiding external interference in domestic and constitutional arrangements" (Sperling 2007, 282). The state is still the referent object of security and the "securitizing agent" (Tow 2016). Although democratic states within the European Union (EU) are treated as post-Westphalian, those in the Asia-Pacific have yet to move in this direction. National security, for instance, continues to shape Australia's foreign policy agenda (Walton and Akimoto 2016).

Moreover, the terror attacks on the United States on September 11, 2001 initiated a backward moving trend in world politics: the global war on terrorism and a renewed emphasis on national security. The US invasions of Afghanistan on October 7, 2001 and Iraq on March 19, 2003 were driven by the United States' policy to reassert its hegemonic positon in world politics (Butt 2019) and produced deadly consequences, such as the global spread of terrorism, the rise of ISIS (Islamic State of Iraq and Syria) and an internationalized civil war in Syria. Geopolitics appears to be making a comeback (Mead 2014), as evidenced by territorial disputes in the East and South China Seas, the Russian annexation of Crimea, and tensions between Iran and the United States. The ongoing trade 'war' between China and the United escalated and is likely to cause collateral damage in the Asia-Pacific. Washington's policy actions in the Middle East added more fuel to the fire when the Trump administration chose to confront Iran on nuclear issues, decided to dispatch 1,500 additional troops and more warships to the region, and sought to expedite arms sales to its allies in the Middle East, namely Saudi Arabia, the United Arab Emirates, and Jordan.

Since the turn of the 21 st century, the world has become increasingly armed. Total global military spending in 2018, for instance, rose to US\$ 1,822 billion. China (with US\$ 250 billion) and the United States (with US\$ 649 billion) alone represent half of the amount (SIPRI 2019a). Global arms sales, similarly, are still moving in a upward trend. In 2017, arms sales and military services by the world's top 100 arms-producing and military services companies reached US\$ 398.2 billion, representing an increase of 44 percent since 2002. The companies based in the United States (with US\$ 226.6 billion) accounted for 57 percent of the amount, followed by those based in Russia (with US\$ 37.7 billion) (SIPRI 2018). According to the Stockholm International Peace Research Institute, "The volume of international transfers of major arms in 2014-18 was 7.8 per cent higher than in 2009-13 and 23 per cent higher than in 2004-2008" (SIPRI 2019a). In Asia and Oceania, to where 40 percent of global arms sales went from 2014 to 2018, the 
five top importers were India, Australia, China, South Korea, and Vietnam. The second largest importer region was the Middle East, which received 40 percent of global arms imports in the same period (SIPRI 2019b).

All this should come as no surprise to anyone, when considering the fact that overall global peace continues to deteriorate. According to Global Peace Index designed to measure global peacefulness, for instance, "the global level of peace has deteriorated by 0.27 per cent in the last year, marking the fourth successive year of deteriorations. Ninety-two countries deteriorated, while 71 countries improved" (Institute for Economics \& Peace 2018, 2). The Index further "reveals a world in which the tensions, conflicts, and crises that emerged in the past decade remain unresolved, especially in the Middle East, resulting in this gradual, sustained fall in peacefulness" (ibid., 2). Although Europe, North America, AsiaPacific, and South America are the four most peaceful regions in the world, they "all recorded deteriorations, with the largest overall deterioration occurring in South America, owing to falls in the Safety and Security domain, mainly due to increases in the incarceration rate and impact of terrorism" (ibid.), as well as other forms of violence such as transnational organized crimes and armed insurgencies. The Middle East and North Africa (MENA) "remains the world's least peaceful region, a position it has held since 2015" (ibid.). Syria, Afghanistan, South Sudan, Iraq and Somalia were among the least peaceful countries. The long and bitter conflict between Israelis and Palestinians remains unresolved. What these findings suggest is that countries that enjoyed the highest level of peacefulness are those that are politically democratic and economically advanced. Thus, political democracy and economic development are necessary if not sufficient conditions for peacefulness - and also for human security.

Armed conflicts and political violence around the world, especially in the Middle East and North Africa, have also produced a large number of refugees, who are among the world's most vulnerable and insecure groups. More than 70 million people had been forced out of their home by 2018 and nearly 30 million of them were refugees. According to a UN report, "the world is witnessing the highest levels of displacement on record" (UN n.d.-a).

A report by the UN Office on Drugs and Crime (UNODC) further shows that homicidal violence in 2017 killed far more people worldwide $(464,000)$ than armed conflict $(89,000)$ and terrorist violence $(26,000)$ in the same year, representing an increase from 362,000 in 1990. According to the report, "Between 2015 and 2017 the total number of homicide victims worldwide increased by 4 per cent, or around 19,000 victims" (UNODC 2019, 12). "If this trend continues," says the report, "target 16.1 ('significantly reduce all forms of violence and related death rates everywhere') under Sustainable Development Goal 16...set in 2015, will not be met by 2030 " (ibid., 12).

When broadly defined, human security as a global policy agenda also remains far from realized. While the overall human development index shows 
a general improvement, global political violence and poverty remains a threat to people. Although "[p]overty rates in the developing world have decreased dramatically over the past decades," according to one study, "several countries covered by this study are at serious risk of democratic backsliding, while globally, democratic standards are equally deteriorating" (Wietzke 2019, 952). According to the UN, moreover, more than 700 million people still live under the international poverty line of US\$ 1.90 a day and most of them belong to Southern Asia and Sub-Saharan Africa. High poverty rates are evident in conflict-affected countries (UNDP 2016). By 2018, many of the 17 Sustainable Development Goals remain unfulfilled. In the Asia-Pacific, where economic growth has been impressive over the last several decades, states are not on track to achieving any of the goals in 2030. According to a UN report (ESCAP 2019), progress in some areas (such as ending poverty, access to quality education, as well as affordable and clean energy) remains limited; however, trends in other areas have been negative. Clean water and sanitation, economic growth and decent work, as well as responsible consumption and production show negative trends.

\section{Some Critical Challenges to Human Security}

The question is: Why is it that the idea of human security appears to have made no significant impact? There may be many reasons, some of which can be identified. Firstly and conceptually, there is no global consensus on what human security means and this makes it difficult for the global policy community to take collective action to address threats to human security. Critics have pointed to the lack of conceptual clarity. Roland Paris (2001) was among the first critics to make the case against the concept by questioning its usefulness because it lacks a precise definition and because its proponents prefer to keep the concept expansive and vague. The underlying ideas of human security are something that most people can talk about, but one of the main challenges is the extent to which it can be operationalized. One of the questions is: If the definition of human security covers almost everything, what is not human security? The discussion around human security has certainly opened a Pandora's Box, meaning different things to different people. Some advocate a "bottom-up" approach (Hanlon and Christie 2016). Others adopt a "top-down" approach in favor of military intervention, economic sanctions, and judicial deterrence (Peou 2014b).

This concept has become amorphous to the point where any collective action required for ensuring the security of individual human beings has become extremely difficult, if not impossible. Some proponents of human security do not subscribe to the UNDP approach. They do not necessarily reject the "freedomfrom-want" dimension of the concept but tend to pay more attention to the other dimension: freedom from fear. They consider this dimension to be in need of 
serious attention. The Canadian government under the liberal leadership of Prime Minister Jean Chretien and his foreign minister, Lloyd Axworthy (2001), took on the challenge of narrowing down the concept of human security by sponsoring the International Commission on Intervention and State Sovereignty, which published The Responsibility to Protect known as R2P (ICISS 2001). This new norm became a globally acknowledged standard when the UN General Assembly endorsed it in what is now known as the 2005 World Outcome Document and the UN Security Council in 2006 passed Resolution 1674 to reaffirm it. The R2P norm is based on three pillars. The first pillar rests on the idea that states have the primary responsibility to protect their populations from war crimes, genocide, ethnic cleansing, and crimes against humanity. The second pillar states that the international community should, as appropriate, encourage and help states to exercise this responsibility. The third pillar stresses the importance of the international community to use peaceful and other means necessary to protect civilian populations against mass atrocities if states themselves fail to do so.

Secondly and theoretically, proponents of human security have engaged in making normative arguments, one of which is that states alone cannot address global challenges such as human rights violations and that international organizations (intergovernmental organizations, international non-profit organizations, and multilateral organizations) should play a greater role. Evidence appears to challenge this normative thinking. Barry Buzan $(2001,589)$ still makes a compelling argument by remarking that states remain "a necessary condition for individual security because without the state it is not clear what other agency is to act on behalf of individuals." As noted earlier, states in Europe and North America are more able than states in other regions when it comes to the question of who is best at providing for human security. What states in these two regions have in common are their democratic values and economic development, as well as economic interdependence. But it is far from clear that international organizations such as the EU are more effective than states since there are no comparable regional institutions in North America. With the United Kingdom in the process of leaving the EU, anti-EU populism, illiberal nationalism and the inability of EU members to speak with one voice on major foreign and defense policy issues, regional integration in Europe is beginning to unravel (Walt 2019; Gramer 2019).

While the state remains the best, if insufficient, actor in ensuring human security, national governments have yet to place the security of individuals beyond their national borders as a top priority on their policy agendas. When they tried to prioritize human security, they either had ulterior motives or failed. Franklin D. Roosevelt (FDR)'s freedom from want and freedom from fear, for instance, were part of a major speech delivered during World War II, but his strategy was aimed at building national consensus in preparation for the United States entering World War II. These two freedoms soon faced a number of critical 
challenges, including the post-World War II rise of American capitalism, the Cold War, the economic crises in the 1970s, and the emergence of neo-liberalism in the 1980s hostile to FDR's government-based approach to dealing with political, social, and economic problems (Jones 2016; Costigliola 2016).

More can be said about human security after the UNDP adopted the concept. The persistence of national security and the resurgence of geopolitics appear to have weakened efforts at human security promotion. Material resources directed toward national or regime security far exceed those allocated for human security. Political realism, whose theoretical merits were called into question after the end of the Cold War, seems to be making a comeback (Walt 2018; Mead 2014; Kaplan 2014; Mearsheimer 2006). Global terrorism, the resurgence of geopolitics (such as competitive territorial claims) and the rise of China are among the recent developments that have precipitated the comeback of realism with its emphasis on national security. The rise of China, with a growing dictatorship under President Xi Jinping who claims to be committed to the SDG agenda, has not only engaged in a trade war with the United States but continues to spend much on defense and protects political regimes that are undemocratic, corrupt, and abusive. Beijing has sought to build a "world-class military" by 2049 (Fravel 2019). China's development assistance has also been accused of working to promote its own national interests, establish security alliances, and undermine efforts by Western democracies to promote democracy, human rights, and good governance (Dreher and Fuchs 2015; Naim 2007; Tull 2006). As the rise of China continues, Japan has also witnessed transformation from a state characterized by commercial pacifism to one that shows an inclination toward realism (Hughes 2016; Green 2001). Japan has built its first aircraft carriers and currently plans to buy more advanced military aircraft (42 F-35s and 105 F-35As) over the next 10 years. Japan, whose military alliance with the United States has survived the Cold War, is revaluating its dependence on the latter's security guarantees as it is confronted with the possibility that the country might need to prepare for war (Smith 2019).

Thirdly, the idea of human security appears to suffer from the implementation of certain policy measures that are proven to be insufficient, ineffective, and even counterproductive. It is interesting to note that Franklin Roosevelt's idea of freedoms did not pave the way for the development of human security after World War II and may have contributed to the strengthening of national security, the emergence of the Cold War, global terrorism and the war on terrorists around the world, and possibly the post-Cold War resurgence of geopolitics. The American president's idea of freedom was evidently designed to prepare the Americans for a collective war against the Axis Powers and, in turn, these ideas did survive his presidency; however, the fear of holocaust, the fear of communism and the enlargement of national security were instead justified in American foreign policy. The four freedoms were pursued "everywhere in the world" (Hitchcock 
2016) and may have produced unintended consequences. The U.S. policy ended up reinforcing and reiterating American exceptionalism, as well as stimulating American imperialism that sparked "hatred intense enough to motivate terrorist attacks on the United States" (Costigliola 2016, 186). The UNDP idea of human security is opposed to imperialism in that individual human beings or humanity are the referent object of security and requires collective action among different actors that include international institutions, but some policy tools used to protect people and promote their security are either ineffective or may have produced undesirable consequences.

\section{The Limits (and Dangers) of Policy Instruments for Human Security}

Specific attention has been given to the promotion of human security through the establishment of various mechanisms and policy instruments, but it is far from clear how effective they have been. The Commission on Human Security, Human Security Network, Global Partnership for the Prevention of Armed Conflict, the Friends of Human Security, and the UN Trust Fund for Human Security all have stood out as collective efforts to promote human security worldwide, but the extent to which they have made a difference remains unknown. Very little is known about the resources they have had at their disposal. Proponents of human security have advocated or adopted a number of policy instruments designed to enhance freedom from fear and freedom from want, including military intervention (peacekeeping and peace enforcement), peace building, smart economic sanctions, and international criminal justice through the establishment of international criminal tribunals and courts (Peou 2014b).

Peace operations-peacekeeping, peace enforcement and peace buildingdo not have an impressive record. Global efforts at global peacekeeping and peace building remain woefully limited (ibid.). Currently the UN Department of Peace Operations leads fourteen peacekeeping missions around the world, most of which are in Africa. As noted, global military spending has increased and far exceeds spending on peacekeeping and peacebuilding. The UN budget approved for the fourteen peacekeeping operations deployed around the world, most of which were in Africa (from July 1, 2018 to June 30, 2019) was only US\$ 6.69 billion miniscule in comparison (UN 2019). Between 2006 and 2017, the UN Peacebuilding Fund, which was designed to prevent a relapse into violent conflict, allocated only US\$ 772 million to forty-one countries (UN n.d.-b).

Peace enforcement or military intervention for human protection has been a controversial topic. For proponents of human security who embrace the norm of Responsibility to Protect (R2P), this form of intervention is necessary when civilian populations are being massacred or come under the threat of mass murder by their own governments. For instance, they view NATO's military 
attacks on Libya in 2011 as the first instance of R2P in action. According to Alex Bellamy $(2011,263)$, this was "the first time that the Security Council has authorized the use of military force for human protection purposes against the wishes of a functioning state." The UN mandate was clear: "there was the extraordinary clarity of the threat of mass atrocities. Not since Rwanda has a regime so clearly signaled its intent to commit crimes against humanity. With direct echoes of Rwanda, Qaddafi told the world that "officers have been deployed in all tribes and regions so that they can purify all decisions from these cockroaches," and that "any Libyan who takes arms against Libya will be executed"' (ibid., 265).

The NATO intervention in Libya was controversial, has been harmful to many people in this country and globally divisive. According to some observers, the mission in Libya was successfully accomplished. The international community was able to take collective action. NATO's Partnership for Peace acted in a legitimate fashion because of international support as well as support from 18 coalition members (including Arab states, such as Jordan, Morocco, and United Arab Emirates). The Gaddafi regime was defeated. The lives of many civilians were saved. Elections in Libya were held in July 2012 (Daalder and Stavridis 2012). The Arab Spring was in full swing. But it has now become clear that the intervention has yet to make the people of Libya more secure. Bellamy (2011) writes "the form of intervention in Libya was highly imperfect, that it delivered indirect and patchy protection at best, and that it placed the region's long-term stability in the hands of fractious rebels about whom little is known" (269; italics added). Developments since 2011 have been detrimental to human security. According to Mark Curtis (2019), "the West's war in Libya spurred terrorism into 14 countries." Alan Kuperman (2015) regards the military action as an "abject failure." Not only has the country "failed to evolve into a democracy," but it also "has devolved into a failed state" (ibid., 67). According to a report by Amnesty International $(2019,1)$, "Militias, armed groups and security forces continued to commit with impunity crimes under international law and gross human rights violations and abuses, including war crimes, throughout the year. Clashes between competing militias resulted in an increased number of civilian casualties. Thousands of people were held indefinitely without any judicial process following arbitrary arrest, including many detained since 2011." Reports by Human Rights Watch (2018) also paint a grim picture of post-2011 Libya. No collective action has been taken in the name of R2P to put an end to the civil war that broke out in 2014 and to human suffering in Syria (Nasser-Eddine 2012), a country that has become a major battleground for geopolitical competition between major powers, most notably Russia and the United States. NATO's intervention in Libya angered Russia, but its failure has also emboldened the latter to play a more active role in the Middle East and Northern Africa (O'Conner 2017).

Economic sanctions as a policy instrument have been adopted by the UN 
and its members, such as the EU and the United States, to change state behavior or stop human rights violations, and to counter terrorism committed by nonstate actors, but it remains a controversial measure. As pointed by one writer, "a targeted sanctions regime is now the preferred Security Council sanctions instrument. Indeed, all of the recent sanctions measures imposed by the Security Council have been targeted" (Stephanides 2002, ix). Since the mid1990s, this policy tool has been refined and implemented to avoid collateral damage (Cortright and Lepez 2002). It is assumed that this policy tool has been effective not only in minimizing pain for vulnerable civilian populations in target countries but also in improving human rights in non-target countries (Carneiro 2014). Some findings, however, suggest that civilian populations in target countries suffer, but those in non-target countries benefit from sanctions. As one scholar puts it, "sanction activity may yield increases in respect for human rights at the global level, but that increase likely comes at the expense of those that live in states where human rights sanctions are imposed" (Clay 2018, 134). This argument remains far from conclusive, as the global human rights situation has deteriorated over the last 13 years. Some scholars even predict the end-times of human rights (Hopgood 2014). Others point to the worldwide retreat of liberal democracy (Freedom House 2019; The Economist 2018).

The "sanctions decade" has not given rise to a global system in which the concept of human security prevails upon those of national and regime security. In fact, sanctions have exacerbated geopolitical competition to the detriment of human security. The recent U.S. sanctions on Iran imposed by the Trump administration, for instance, have not only harmed the Iranian economy but also "empowered anti-US forces within Iranian politics, and armed conflict with the US remains a possible outcome" (IISS 2019). The sanctions imposed on Syria have resulted in human suffering, despite the fact that its government has been the target. Nour Samaha (2019) is correct in making the conclusion that "sanctions can never be 'smart." Instead of weakening the repressive regime in Syria, the U.S. and E.U. sanctions have strengthened it. In her view, the West "needs to be far more honest about the counter-productiveness of a tool, and particularly sectoral sanctions, which will produce little in its stated intentions and instead have a detrimental impact on the wider population" (ibid.).

The pursuit of international criminal justice also does not appear to become more effective than the use of military force and economic sanctions, despite the optimistic assumption that international criminal tribunals and courts would be able to help end armed conflicts and mass atrocities or deter them. The establishment of the International Criminal Court (ICC) in 2002 does not seem to have produced any significant effects on the actions of political regimes that violate human rights or threaten the security of their own people. The ICC and other criminal tribunals such as the International Criminal Court for the former Yugoslavia, the International Criminal Tribunal for Rwanda, and the 
Extraordinary Chambers in the Court of Cambodia have yet to make many parts of the world safer for civilian populations. Cambodia has moved away from a nascent democracy back toward a one-party state (Peou 2019). Many countries in East Asia, are still under authoritarian or military rule. Ethnic violence is still pervasive in Myanmar, where ethnic cleansing has been committed by the military-dominated regime against Rohingya civilians. Armed conflicts and human rights violations continue unabated in the Middle East. According to one scholar, "neither the ICC nor R2P can confront the underlying causes of many conflicts: to do that requires a commitment to radical change in international economics, not international politics or international law" (Ainley 2015, 53).

The "decade of international law" has yet to effectively weaken the realist idea of state security, but Kirsten Ainley's (2015) point further raises the question of whether economic growth and radical change alone would produce better results in the enhancement of human security. Economic growth in Africa appears to be insufficient in ensuring the security of people on the continent because of poor national governance. As previously noted, Africa is still among the least peaceful regions. Although states in East Asia have enjoyed impressive economic growth, many of their people remain insecure. States that are economically developed or developing (such as Australia, China, India, Japan, South Korea, and Vietnam) tend to increase defense spending or maintain high defense expenditures. Most noteworthy is the fact that Japan, one of the world's most developed countries, used its newfound wealth to complete its rearmament in the late 1980s by turning its Self-Defense Forces into a modern, technologically advanced force (Smith 2019). World history still leaves us wondering if a non-capitalist international system would bring about peace and security, as wars broke out before the emergence of world capitalism and were fought between socialist states (China and the Soviet Union in the late 1960s, Cambodia and Vietnam in the late 1970s, and China and Vietnam in 1979) during the Cold War.

All in all, the global use of military, economic and judicial threat to change bad political behavior since the 1990s has not given rise to an international system based on the idea of human security. From Cambodia to Indonesia and East Timor and from Myanmar to North Korea, the threat of punishment directed at ruling elites tend to be ineffective or detrimental to the security of civilian populations (David and Holliday 2006; Peou 2016, 2014a). Instead of giving up power, authoritarian leaders tend to hunker down when they come under threat and hold on to power even if it means causing human suffering. According to their work on Myanmar, for instance, Roman David and Ian Holliday $(2012,136)$ argue that, "our experts defied much activist opinion in holding that revoking both policies had the best chance of promoting thoroughgoing reform inside the country." Their experts advocated a combination of policy actions: the lifting of sanctions and guarantees of non-prosecution. Thus, proponents of sanctions, judicial punishment or its threat and military humanitarian intervention may 
need to reflect more critically on the fact these policy tools may have been historically ineffective and may contribute to human insecurity.

\section{Conclusion and Additional Points for Consideration}

Overall, the first decade of the 21 st century saw the beginning of a general decline of policy interest in the promotion of human security and the future of humanity is far from certain since states are far from obsolete and international organizations as well as non-state actors have yet to become the primary agents of change. This was the main reason we invited a number of scholars to reflect on the challenges that still confront the promise of human security. The next four articles cover human security in East Asia, human security in Africa, military intervention, and smart sanctions. These articles appear to validate some of the major arguments and propositions made in this article.

In his article on "Human Security, Peacebuilding, and the Responsibility to Protect in East Asia," Brendan Howe uses country case studies to explain why the idea of protecting people has encountered difficult challenges. Driven by the need to defend state sovereignty and give priority to national security, states in East Asia continue to not embrace the norm of global intervention, especially when involving the use of military force within the context of R2P, but have instead placed emphasis on the need to prevent threats to human security through providing assistance for economic development. With that said, according to Howe, "East Asian actors and commentators have certainly become more engaged with the discourse, and this analysis of human security and the R2P in East Asia shows that the region is no longer the preserve of Westphalian statecentricity and sovereignty it has often been depicted."

The extent to which the development-based approach officially or unofficially espoused by states, especially those in East Asia, can fully ensure the security of civilian populations is a subject of debate, but it is clear that too much emphasis on the need to ensure economic welfare also has its limitations. Economic growth alone has not been effectively translated into freedom from fear in East Asia, as threats to human rights continue and as prosperous states still spend more on national defense than on basic human needs. Only a handful of democratic states in East Asia have also been able to ensure freedom from fear. As further shown in the article entitled "Governance Perspectives of Human Security in Africa" by Kwesi Aning and Ernest Ansah Lartey the lack of democratic governance has been a major challenge to the idea of human security in the African region. According to the author, "in spite of all the plaudits about increasing economic growth in the region, poverty, hunger and diseases continue to expose weaknesses in the development paradigms and policies of most African countries." Without a system of government that holds political leaders accountable for their policy 
actions, it is unlikely that even the requirements of economic welfare can be effectively met and sustained. The security sector needs urgent and effective reform.

While the system of democratic governance that is both accountable and transparent may be necessary for the promotion of freedom from fear (and freedom from want), it is far from clear how this objective can be achieved under certain dire circumstances. What if the environment for economic development is hindered by war and political violence? Would the use of force to end them be an effective tool? Would economic sanctions work better? Would the threat of judicial punishment help promote peace and democracy?

The last two articles seek to answer these questions. Mats Berdal's article "Revisiting the "Responsibility to Protect" makes it clear that this type of military intervention continues to keep UN member states divided. Although the norm of R2P "has gradually come to command broad support from States," it has made "scant difference" even when it matters most. Resistance to the norm continues. Berdal makes an argument in addition to one of the points advanced in this article namely that the use of military intervention in the form of R2P as evidenced by the NATO intervention in Libya exacerbated geopolitical competition among the great powers. In his words, "Rising geopolitical tensions, reflected in the breakdown of political relations among key members of the Security Council, have only added to a growing sense of pessimism among R2P advocates." As noted earlier, the R2P type of intervention in the case of Libya also helped precipitate the resurgence of geopolitics to the detriment of human security by making it extremely difficult, if not impossible, for the international community to intervene militarily for human protection elsewhere.

A similar argument is made in the last article entitled "Why Smart Sanctions Still Cause Human Insecurity?” by Sorpong Peou. The author examines the optimistic proposition that multilateral and bilateral economic sanctions have been made smart in that this policy tool is capable of preventing collateral damage while getting target state leaders to change their policy behavior or actions such as human rights violations. Two case studies, the sanctions on North Korea and Myanmar, are adopted to test this proposition. Empirical evidence shows otherwise: economic sanctions have not become smart enough due to the fact that targeted state leaders are capable of outsmarting sanctions sending actors. In fact, this policy instrument has perpetuated human insecurity on different levels, including failure to undermine authoritarian regime leaders and to protect people from threats and freedom from fear. Instead of making policy changes in conformity to the terms of sanctions, the state leaders of these two authoritarian regimes have maintained high defense spending to justify the need for national defense while their primary concern has clearly been centered on regime security. In addition, they have developed closer relations with powerful authoritarian states like China and Russia. What available evidence shows is that 
the target leaders of these two states are, first and foremost, either willing or able to protect their regime at any cost or at the cost of civilian populations despite the lack or decline of its political legitimacy.

In short, what this special issue clearly shows is that proponents of human security may need to acknowledge that their vision for a better world through securing humanity is far from realized and in many ways has seen a reversal in recent years. They also need to think harder about some of the policy measures and instruments adopted and implemented so far-and much harder still about the consequences of what we actually do and not simply what we ought to do.

\section{Acknowledgements}

I am grateful for the critical but constructive comments from the Asian Journal of Peacebuilding's peer-review process.

\section{References}

Ainley, Kirsten. 2015. “The Responsibility to Protect and the International Criminal Court: Countering the Crisis." International Affairs 91 (1): 37-54.

Amnesty International. 2019. Human Rights in the Middle East and North Africa: Review of 2018. Amnesty International. February 26.

Axworthy, Lloyd. 2001. "Human Security and Global Governance: Putting People First." Global Governance 7: 19-23.

Bellamy, Alex. 2011. "Libya and the Responsibility to Protect: The Exception and the Norm." Ethics \& International Affairs 25 (3): 263-69.

Brainard, Lael, Abigail Jones, and Nigel Purvis, eds. 2009. Climate Change and Global Poverty: A Billion Lives in the Balance? Washington, DC: Brookings Institution Press.

Butt, Ahsan. 2019. “Why Did the United States Invade Iraq in 2003?” Security Studies 28 (2): 250-85.

Buzan, Barry. 2001. "Human Security in International Perspective." In The Asia-Pacific in the New Millennium: Political and Security Challenges, eds. M. C. Anthony and M. J. Hassan. Kuala Lumpur: Institute of Strategic and International Studies, 583-96.

Carneiro, Christiane De Andradelucena. 2014. "Economic Sanctions and Human Rights: An Analysis of Enforcement Strategies in Latin America." Bras. Polit. Int. 57 (1): 197215.

Clay, K. Chad. 2018. Threat by Example: Economic Sanctions and Global Respect for Human Rights. Journal of Global Security Studies 3 (2): 133-49.

Cortright, David, and George Lepez. 2000. The Sanctions Decade. Assessing UN Strategies in the 1990s. Boulder, CO: Lynne Reiner.

Cortright, David, and George Lepez, eds. 2002. Smart Sanctions: Targeting Economic Statecraft. New York: Rowman \& Littlefield Publishers.

Costigliola, Frank. 2016. “Freedom from Fear." In The Four Freedoms: Franklin D. Roosevelt 
and the Evolution of an American Idea, ed. Jeffrey Engel. New York: Oxford University Press.

Courtois, Stéphanie, Nicolas Werth, Jean-Louis Panné, Andrzej Paczkowski, Karel Bartošek, and Jean-Louis Margolin. 1999. The Black Book of Communism: Crimes, Terror, Repression. Cambridge, Massachusetts: Harvard University Press.

Curtis, Mark. 2019. "How the West's War in Libya Spurred Terrorism into 14 Countries." Consortium News 25 (170). https://consortiumnews.com/2019/05/21/how-the-westswar-in-libya-spurred-terrorism-in-14-countries (accessed November 28, 2019).

Daalder, Ivo H., and James G. Stavridis. 2012. "NATO’s Victory in Libya: The Right Way to Run an Intervention." Foreign Affairs 91 (2): 2-7.

David, Roman, and Ian Holliday. 2006. "Set the Junta Free: Pre-transitional Justice in Myanmar's Democratization.” Australian Journal of Political Science, 41 (1): 91-105.

David, Roman, and Ian Holliday. 2012. "International Sanctions or International Justice? Shaping Political Development in Myanmar." Australian Journal of International Affairs 66 (2): 121-38.

Dreher, Axel, and Andrea Fuchs. 2015. "Rogue Aid? An Empirical Analysis of China's Aid Allocation." Canadian Journal of Economics 38 (3): 988-1023.

Engel, Jeffrey, ed. 2016. The Four Freedoms: Franklin D. Roosevelt and the Evolution of an American Idea. New York: Oxford University Press.

ESCAP (United Nations Economic and Social Commission for Asia and the Pacific). 2019. Asia and the Pacific SDG Progress Report 2019. Bangkok, Thailand: ESCAP.

Fravel, M. Taylor. 2019. Active Defence: China's Military Strategy since 1949. Princeton and Oxford: Princeton University Press.

Freedom House. 2019. Freedom in the World 2019: Democracy in Retreat. https:// freedomhouse.org/sites/default/files/Feb2019_FH_FITW_2019_Report_ForWebcompressed.pdf (accessed November 28, 2019).

Gramer, Robbie. 2019. “How European Politics Is Fracturing." Foreign Policy. May 28.

Green, Michael. 2001. Japan's Reluctant Realism. New York: Palgrave Macmillan.

Hanlon, Robert J., and Kenneth Christie. 2016. Freedom from Fear, Freedom from Want: An Introduction to Human Security. Toronto, Canada: University of Toronto Press.

Hitchcock, William. 2016. "Everywhere in the World." In The Four Freedoms: Franklin D. Roosevelt and the Evolution of an American Idea, ed. Jeffrey Engel. New York: Oxford University Press.

Hopgood, Stephen. 2014. The Endtimes of Human Rights. Ithaca: Cornell University Press.

Hoshino, Toshiya, and Haruko Satoh. 2016. "Japan and an Emerging Approach to Human Security: A 'Tokyo Consensus'?” In New Approaches to Human Security in the AsiaPacific: China, Japan and Australia, eds. William Tow, David Walton, and Rikki Kirsten. New York: Routlege.

Hughes, Christopher. 2016. “Japan’s 'Resentful Realism' and Balancing China’s Rise.” The Chinese Journal of International Politics 9 (2): 109-50.

Human Rights Watch. 2018. "Libya: Events of 2017." World Report 2018. https://www.hrw. org/world-report/2018/country-chapters/libya (accessed November 28, 2019).

ICISS (International Commission on Intervention and State Sovereignty). 2001. The Responsibility to Protect: Report of the International Commission on Intervention and State Sovereignty. Ottawa: International Development Research Centre.

IISS (International Institute for Strategic Studies). 2019. The Impact of Renewed Sanctions 
on Iran 25 (February). https://www.iiss.org/publications/strategic-comments/2019/ the-impact-of-renewed-sanctions-on-iran (accessed on May 29, 2019).

Institute for Economics \& Peace. 2018. Global Peace Index 2018: Measuring Peace in a Complex World, Sydney (June). Available from: http://visionofhumanity.org/reports (accessed on May 27, 2019).

Jiadong, Zhang, and Zheng Xin. 2016. "Human Security in China: A New Approach." In New Approaches to Human Security in the Asia-Pacific: China, Japan and Australia, eds. William Tow, David Walton, and Rikki Kirsten. New York: Routledge.

Jones, Matthew. 2016. "Freedom from Want." In The Four Freedoms: Franklin D. Roosevelt and the Evolution of an American Idea, ed. Jeffrey Engel. New York: Oxford University Press.

Kaplan, Robert. 2014. Asia's Cauldron: The South China Sea and the End of a Stable Pacific. New York: Random House.

Kuperman, Alan J. 2015. “Obama’s Libya Debacle: How a Well-Meaning Intervention Ended in Failure." Foreign Affairs 94 (2): 66-77.

MacFarland, S. Neil, and Yuen Foong Khong. 2006. Human Security and the UN: A Critical History. Bloomington and Indianapolis: Indiana University Press.

Mead, Walter Russell. 2014. "The Return of Geopolitics: The Revenge of Revisionist Powers." Foreign Affairs (March-April): 69-79.

Mearsheimer, John. 2006. “China’s Unpeaceful Rise.” Current History (April): 160-62.

Mohajan, Haradhan Kumar. 2015. "Sustainable Development Policy of Global Economy." American Journal of Environmental Protection 3 (1): 12-29.

Naim, Moises. 2007. "Missing Links: Rogue Aid." Foreign Policy (159): 95-96.

Nasser-Eddine, M. 2012. "How R2P Failed Syria." Flinders Journal of History and Politics 28: 16-30.

O'Conner, Tom. 2017. "Russia Claims Victory in Syria War, Now Moscow Has Its Eyes on Libya Crisis." Newsweek. December 12. https://www.newsweek.com/russia-claimvictory-syria-war-moscow-has-eye-libya-crisis-746069 (accessed November 28, 2019).

Paris, Roland. 2001. "Human Security: Paradigm Shift or Hot Air?" International Security 26 (2): 87-102.

Peou, Sorpong, ed. 2009. Human Security in East Asia: Challenges for Collaborative Action. London: Routledge.

Peou, Sorpong. 2014a. Human Security Studies: Theories, Methods and Themes. Singapore \& Hackensack, NJ: World Scientific \& Imperial College Press.

Peou, Sorpong. 2014b. “The Limits and Potential of Liberal Peacebuilding." Asian Journal of Peacebuilding 2 (1): 37-60.

Peou, Sorpong. 2016. "Peace through Retribution or Reconciliation? Some Insights and Evidence from Southeast Asia." In The Palgrave Handbook of Disciplinary and Regional Approaches to Peace, eds. Oliver P. Richmond, Sandra Pogodda, and Jasmin Ramovic. Hampshire, UK: Palgrave Macmillan, 336-49.

Peou, Sorpong. 2019. "Cambodia in 2018: A Year of Setbacks and Successes." In Southeast Asian Affairs 2019, eds. Daljit Singh and Malcolm Cook. Singapore: Institute of Southeast Asian Studies - Yusof Ishak Institute.

Samaha, Nour. 2019. “The Economic War on Syria: Why Europe Risks Losing." The European Council on Foreign Relations. February 11. https://www.ecfr.eu/archives/ 
C315 (accessed November 28, 2019).

SIPRI (Stockholm International Peace Research Institute). 2018. "Global Arms Industry: US Companies Top the 100 Companies; Russian Arms Industry Moves Second Place." https://www.sipri.org/media/press-release/2018/global-arms-industry-us-companiesdominate-top-100-russian-arms-industry-moves-second-place (accessed November 28, 2019).

SIPRI (Stockholm International Peace Research Institute). 2019a. "World Military Expenditures Rose to \$1,8 in 2018." https://www.sipri.org/media/press-release/2019/ world-military-expenditure-grows-18-trillion-2018 (accessed November 28, 2019).

SIPRI (Stockholm International Peace Research Institute). 2019b. "Global Arms Trade: USA Increases Dominance; Arms Flows to the Middle East Surge, Says SIPRI." https://www.sipri.org/media/press-release/2019/global-arms-trade-usa-increasesdominance-arms-flows-middle-east-surge-says-sipri (accessed November 28, 2019).

Small, Michael. 2016. Should Canada Revisit the Human Security Agenda? 2016 Policy Review Series. Calgary. Alberta: Canadian Global Affairs Institute.

Smith, Sheila A. 2019. Japan Rearmed: The Politics of Power. Cambridge, MA, \& London, UK: Harvard University Press.

Sperling, James. 2007. "Regional or Global Security Co-operation? The Vertices of Conflict and Interstices of Cooperation." In Global Security Governance: Competing Perceptions of Security in the 21st Century, eds. Emil J. Kirchner and James Sperling. New York, NY: Routledge.

Stephanides, Joseph. 2002. "Foreword." In Smart Sanctions: Targeting Economic Statecraft, eds. David Cortright and George Lepez. New York: Rowman \& Littlefield Publishers.

The Economist. 2018. "After Decades of Triumph, Democracy is Losing Ground.” June 14. https://www.economist.com/international/2018/06/14/after-decades-of-triumphdemocracy-is-losing-ground (accessed November 28, 2019).

Tadjbakhsh, Shahrbanou. 2014. Human Security Twenty Years On. Oslo, Norway: Norwegian Peacebuilding Resource Centre.

Tow, William. 2016. "Introduction." In New Approaches to Human Security in the AsiaPacific: China, Japan and Australia, eds. William Tow, David Walton, and Rikki Kirsten. New York: Routledge.

Tull, Denis M. 2006. "China's Engagement in Africa: Scope, Significance and Consequences." Journal of Modern African Studies 44 (3): 459-79.

UN (United Nations). n.d.-a. "Refugees." https://www.un.org/en/sections/issues-depth/ refugees (accessed November 1, 2019).

UN (United Nations). n.d.-b. “United Nations Peacebuilding Fund.” https://www.un.org/ peacebuilding/fund (accessed November 1, 2019).

UN (United Nations). 2019. “Peacekeeping." https://peacekeeping.un.org/en/data (accessed November 28, 2019).

UNDP (United Nations Development Programme). 1994. Human Development Report 1994: New Dimensions of Human Security. New York: Oxford University Press.

UNDP (United Nations Development Programme). 2016. "Ending Poverty by 2030: UNDP's Perspective and Role." Issue Brief (March). https://www.undp.org/content/ $\mathrm{dam} /$ undp/library/Sustainable\%20Development/ISSUE_BRIEF_Ending_Poverty_ by_2030.pdf (accessed November 28, 2019).

UNODC (United Nations Office on Drugs and Crime). 2019. Global Study on Homicide: 
Executive Summary. Vienna, Austria: United Nations Office on Drugs and Crime. https://www.unodc.org/documents/data-and-analysis/gsh/Booklet1.pdf (accessed November 28, 2019).

Walt, Stephen. 2018. "What Sort of World Are We Headed For? The Liberal World Never Really Existed. Great Power Politics Are Here to Stay.” Foreign Policy. October 2.

Walt, Stephen. 2019. "Be Afraid of the World, Be Very Afraid." Foreign Policy. May 20.

Walton, David, and Daisuke Akimoto. 2016. "The Human Security Agenda: Australia and Japan." In New Approaches to Human Security in the Asia-Pacific: China, Japan and Australia, eds. William Tow, David Walton, and Rikki Kirsten. New York: Routledge.

Wietzke, Frank-Borge. 2019. "Poverty Reduction and Democratization - New Crosscountry Evidence." Democratization 26 (6): 935-58.

World Commission on Environment and Development. 1987. From One Earth to One World: An Overview. Oxford: Oxford University Press.

Xiao, Ren, and Yanxing Li. 2016. "A Return to People: China's Approach to Human Security." In New Approaches to Human Security in the Asia-Pacific: China, Japan and Australia, eds. William Tow, David Walton, and Rikki Kirsten. New York: Routledge.

Sorpong Peou is Professor of Global Peace and Security Studies, Department of Politics and Public Administration, Ryerson University, Toronto, Canada, where he also served as Department Chair. He also served as President of Science for Peace, Canada, and Chair of the Department of Political Science, the University of Winnipeg, Manitoba, Canada. Prior to these academic and administrative appointments, he was Professor of International Security, Sophia University, Tokyo (Japan), and Fellow/ASEAN-Canada Fellow at the Institute of Southeast Asian Studies, Singapore. Email: speou@ politics.ryerson.ca. 
